\title{
The Global Partnership for Education's evolving support to fragile and conflict-affected states
}

\section{Citation}

Menashy, Francine, and Sarah Dryden-Peterson. 2015. “The Global Partnership for Education's Evolving Support to Fragile and Conflict-Affected States." International Journal of Educational Development 44 (September): 82-94.

\section{Published Version}

doi:10.1016/j.ijedudev.2015.07.001

\section{Permanent link}

http://nrs.harvard.edu/urn-3:HUL.InstRepos:25378642

\section{Terms of Use}

This article was downloaded from Harvard University's DASH repository, and is made available under the terms and conditions applicable to Open Access Policy Articles, as set forth at http:// nrs.harvard.edu/urn-3:HUL.InstRepos:dash.current.terms-of-use\#OAP

\section{Share Your Story}

The Harvard community has made this article openly available.

Please share how this access benefits you. Submit a story.

\section{Accessibility}




\title{
Title:
}

The Global Partnership for Education’s Evolving Support to Fragile and Conflict-Affected States

\section{Authors:}

Francine Menashy (Corresponding Author)

University of Massachusetts Boston Department of Leadership in Education University of Massachusetts Boston 100 Morrissey Blvd Boston, MA 02125 Office W04-119

Phone: 617-287-3163

Email: francine.menashy@umb.edu

Sarah Dryden-Peterson

Harvard Graduate School of Education

Appian Way

Cambridge, MA 02138

Office Gutman 457

Phone: $617-495-8142$

Email: sarah_dryden-peterson@gse.harvard.edu

\begin{abstract}
In this study, we trace the history of policy development within the Global Partnership for Education to discern the drivers behind the uptake of its shifting policies relating to education in fragile and conflictaffected states. In order to elucidate how and why this international organization has altered its policy stance and funding modalities, we employ a process tracing analysis of document and interview data. Moreover, we provide three country case studies of Global Partnership for Education financing to Liberia, Madagascar, and the Democratic Republic of the Congo.
\end{abstract}

\section{Funding Source}

This study has been supported by a National Academy of Education/Spencer Foundation postdoctoral fellowship and a Joseph P. Healey Research Grant from the University of Massachusetts Boston. 


\section{The Global Partnership for Education's Evolving Support to Fragile and Conflict-Affected States}

\section{Introduction}

The number of children living in fragile and conflict-affected contexts has escalated in recent years. In 2014, 230 million children lived in countries affected by armed conflict (UNICEF, 2014), and more than 52 million children were living as refugees or internally displaced peoples, the largest scale of displacement ever recorded (UNHCR, 2014b; UNICEF, 2014; Watkins \& Zyck, 2014). The effects of fragility and conflict on education are devastating both in the shortterm and over the long-term. Of the 57 million children who remain out of school globally, almost half live in these settings (UNESCO, 2014). The United Nations High Level Panel report on the Post-2015 Development Agenda identifies five big, transformative shifts that are necessary in order to end poverty and promote sustainable development. The first is to "leave no one behind" (United Nations, 2013). To act on this goal, the education of children in fragile and conflict settings is an urgent priority.

Over the past decade, there has been a shift in global policy toward prioritizing education in settings of fragility and conflict (Winthrop \& Matsui, 2013). Normative standards in the form of the Minimum Standards for Education were first published by the Inter-Agency Network for Education in Emergencies in 2004 (INEE, 2004) and revised and updated in 2010 (INEE, 2010). In 2010, the United Nations General Assembly passed a resolution on the right to education in emergencies, which urges concerted international effort to ensure that all children living in conflict have access to education (United Nations, 2010). Key high-profile individuals contributed to the elevation of this issue on the global policy agenda. For instance, in 2012, UN Secretary General Ban Ki-moon selected former UK Prime Minister Gordon Brown as Special Envoy on Global Education to lead the newly established Education First Initiative, which identifies sustaining education in humanitarian crises, especially conflict, as a key action to addressing the global education emergency. Also contributing to the rise of this issue on the global agenda, a number of international non-governmental organizations and private foundations (including Save the Children, ActionAid and Oxfam International) began to include education in contexts of conflict and fragility as a priority.

At the same time, Official Development Assistance (ODA) to education in these contexts has historically been low, focused on "good performers." With evidence that aid works better in countries with stronger institutions and more effective policy regimes (Burnside \& Dollar, 2000), good governance was a prerequisite for investment. Fragile states, which by definition are settings where governance is threatened, received only 18 percent of all global aid to education between 2003 and 2005, and 21 percent between 2005 and 2007 (Save the Children, 2009, pp. vi, 3,42 ). While education ODA commitments to other low-income countries rose from US\$2 billion in 1999 to US\$3.8 billion in 2006 , they increased from only US $\$ 0.5$ billion to US $\$ 0.9$ billion in fragile states (Turrent \& Oktech, 2009, p. 360).

Actual aid commitments did not follow the recognized need and the rhetorical prioritization of education in settings of conflict and fragility. In this context, the 2012 decision by the Global Partnership for Education to prioritize education in fragile and conflict-affected states represented a surprising and important shift. The Global Partnership for Education (GPE) was 
initially launched in 2002 as the Education for All Fast Track Initiative (FTI), a multistakeholder agency spearheaded by the World Bank, with the goal of galvanizing donor funding in order to put any developing country with a credible plan on a "fast track" to achieving education for all. Given strict eligibility requirements, very few countries experiencing conflict or fragility were able to secure funding from the FTI. However, upon the FTI's 2011 restructuring into the Global Partnership for Education, the issues of conflict and fragility rose rapidly on the policy agenda of the organization and was reflected in its distribution of funding.

Of its 59 recipient countries in 2014, the GPE supported 28 countries experiencing fragility or conflict (Global Partnership for Education, 2014d), ${ }^{1}$ double the number since 2010. In 2013, 52 percent of the total GPE funding distributions were for states affected by fragility and conflict, up from only 13 percent in 2010 (Global Partnership for Education, 2014e, p. 12). Importantly, support to education in fragile and conflict-affected states is listed as the first objective in the GPE's 2012-2015 Strategic Plan. Upon discovering the prioritization of fragile and conflictaffected settings in the GPE Strategic Plan, a senior development actor in the field of education in conflict commented: "I got to tell you, I was shocked" (Interview \#5). Such a rapid shift in terms of mandate and operations signifies a case of a substantial institutional change. How did it occur?

In this paper, our objective is to trace the history of policy development within the FTI/GPE to discern the drivers behind the uptake of its policies relating to education in fragile and conflictaffected states. To gain a more comprehensive understanding of the complexity of funding to settings of conflict and fragility, we provide three country case studies of GPE financing to Liberia, Madagascar, and the Democratic Republic of the Congo (DRC). In order to elucidate how and why this international organization has altered its policy stance and funding modalities, we employ a process tracing analysis of document and interview data. By investigating the key past events within the FTI/GPE relating to the support of fragile and conflict-affected states, we aim to uncover how this issue has been elevated on the agenda of the organization.

Our study, conceptually situated within the theoretical international relations literature on institutional change, empirically establishes a shift in how state fragility is understood and addressed in international education policy. In doing so, it offers a case where an organization has altered its policies in order to better address global needs. Our analysis indicates that this change occurred as a result of the convergence of a number of factors both internal and external to the GPE, including a broader normative consensus on the gravity of the issue and the actions of individual policy entrepreneurs within the GPE leadership and on its Board of Directors. Theoretically, this study offers many insights into how institutional policy-making can shift. It also offers insights into the specific uptake by one organization of education in fragility and

\footnotetext{
${ }^{1}$ We use the term "fragile and conflict-affected states," as this is the term the used by the GPE. The Global Partnership for Education uses the definitions of the World Bank and the UNESCO Global Monitoring Report to define fragile and conflict-affected contexts. This definition includes countries that are or have recently experienced armed conflict and/or fragility, the latter defined as countries that are "failing to provide basic services to poor people because they are unwilling or unable to do so" (OECD, 2007). The 28 countries supported as of January 2015 by the GPE that fits this categorization are: Afghanistan, Burundi, Central African Republic, Chad, Comoros, Côte d'Ivoire, Democratic Republic of Congo, Eritrea, Ethiopia, Guinea-Bissau, Haiti, Liberia, Madagascar, Malawi, Mali, Nepal, Niger, Nigeria, Pakistan, Sierra Leone, Somalia, South Sudan, Sudan, Timor Leste, Togo, Uganda, Yemen, and Zimbabwe.
} 
conflict as a policy priority, with lessons for understanding the broader proliferation of this priority.

The GPE, as the largest multi-stakeholder partnership in education, is a unique entity in the educational arena due to its pooled funding mechanisms and the combination of an array of very diverse actors in its policy-making processes. It arguably represents a shift in policy priority among the broader group of actors that comprise its membership, including donor and recipient governments, UN agencies, iNGOs, foundations, and corporations. Furthermore, through tracing the factors that motivated these different actors to arrive at consensus within the GPE, this case study can allow researchers of international relations to better understand shifts in other largescale multi-stakeholder organizations, which have been endorsed through international agreements and are proliferating in many areas, such as health and the environment ("Rome Declaration on Harmonisation," 2003; Savedoff, 2012). This study and its findings therefore offer significant insights into the new and growing arena of collaborative and inter-institutional decision-making on global public policies and can inform how international partners approach and understand change within their own large and complex organizations. In this way, our research contributes to the wider international development literature-targeting audiences including scholars, practitioners in aid organizations, and policy-makers — on the new and growing trends of pooled funding, coordination, and collaboration by exposing (a) how multistakeholder policies are spearheaded and adopted; (b) what triggers funding mechanisms to evolve and adapt; and (c) some key current challenges associated with global financing to fragile contexts.

\section{Conceptual Framework: Historical Institutionalism and Drivers of Change}

Our study points to an interesting case where an international organization has altered its policy position and operational practices over a relatively short period of time, and our research asks what drove these changes. In light of this, the conceptual literature on institutional change from the field of international relations helps us to examine the case of the Global Partnership for Education and its evolving positions on fragile and conflict-affected states over the period 2002 to 2014.

Our analysis is informed particularly by historical institutionalism. We seek to study how institutions change by tracing the dynamics within an organization, such as the internal rules and associated behaviors that shape how a bureaucracy operates, and how an organization responds to external pressures. We are particularly interested in how bureaucratic norms evolve over time. Under this approach, policy-making processes are understood to be governed primarily by past formal rules and procedures, which over time have shaped the ideas that are taken seriously and thereby the actions employed by an organization. Change occurs as a result of internally and historically constituted institutional characteristics but also in conjunction with drivers from outside the organization (Barkin, 2006; Campbell, 1998, 2002, 2007; Hall, 2010).

We therefore expect institutional change to result from both external and internal forces. In all cases, institutional change is context specific, and the influences need to be evaluated not only by looking at the present state of an organization, but also by rigorously examining its history. International relations researchers have identified multiple sources of change, which tend to 
combine exogenous and endogenous factors. These include structural shifts, including changes in the global policy landscape triggering changes in an individual organization's governance models. For example, a key element of new forms of global governance in education has been the inclusion of the non-state sector (Ball, 2012). If private or civil society actors are included in decision-making within an IO, their standpoints and actions may have significant impacts on the direction taken by the organization as a whole (Campbell, 2007; Kapur, 2000). Broader normative shifts also push organizations to change, where "some norms gradually garner legitimacy on the basis of mounting evidence that is underpinned by a solid body of research" and if an organization does not adapt in order to embrace such norms, it may encounter a loss of legitimacy (Campbell, 2007; Hefler, 2006; Kapur, 2000).

Kingdon's work on policy formation and agenda-setting is also helpful in understanding this case. He uses the concept of problem recognition to describe how particular issues "capture the attention" of actors in policy circles (Kingdon, 2011, p. 87). Change happens when problem recognition dovetails with the actions of individual actors or "policy entrepreneurs." Such entrepreneurs are those who act as advocates for specific causes and hold particular leadership and intellectual characteristics, along with a strong degree of social and cultural capital and so can entice change from within an organization (Ball, 2012; Campbell, 2007; Kingdon, 2011). Kingdon describes policy entrepreneurship in the context of the push for particular agendas within policy communities, where various actors propose solutions to problems or alternatives to current policies. These entrepreneurs can also be depicted as key advocates for particular ideas or proposals (Kingdon, 2011, p.122).

Our examination of the GPE centers on the history of its engagement with fragile and conflictaffected states, at both the global policy and the country level. Our study shows that all the above factors - namely, structural changes, normative shifts and problem recognition, and the role of policy entrepreneurs - contributed to the GPE's shift in policy, and were driven from the global to the country level. Through our historical tracing of GPE policy-making processes, we identify key influences from both outside the organization and within it that have pushed originally the FTI, and then its successor, the GPE, to evolve and shift its positions on support to fragile and conflict-affected states. Through detailed country case studies, we show how this evolving support directly impacted countries experiencing different degrees of fragility and conflict.

\section{Methods}

In this paper, we provide a case study analysis using a process tracing method. Employed as an analytical device for understanding historical processes and their outcomes, process tracing uses pieces of evidence to draw inferences about past events to develop an account that helps to shed light on the causes of particular outcomes (Bennett, 2010; Collier, 2011). In order to determine the historical drivers behind the FTI/GPE's shifting policies relating to education in fragile and conflict-affected states, we have analyzed 21 key documents produced by the FTI/GPE between 2004 and 2014. After a review of all documents publicly available on the GPE website library as of October 2014, fourteen documents were selected for analysis due to their direct relevance to the support of fragile and conflict-affected states and/or on the basis of their focus relating to financing mechanisms. Seven summative meeting reports were also included in our sample from GPE Board of Directors meetings in order to examine how the issue of education in fragile and conflict-affected states was taken up at the governance level of the partnership; these seven 
reports included at least one from each Board meeting since the 2011 restructuring. For details on the key documents analyzed, see Appendix A. In addition, using NVivo qualitative research software, we conducted a word frequency analysis of over 100 publicly available documents from FTI/GPE Board of Directors meetings since 2009. Included in the NVivo analysis were the 21 documents described above as well as all other available meeting documents, including presentations, CEO statements, board decisions documents, sub-committee reports, secretariat reports, budget reports, and minutes of meetings.

Our analysis is moreover informed by semi-structured interviews, conducted individually with key stakeholders who have intimate knowledge of the FTI/GPE and its historical support to fragile and conflict-affected states. In total, eight in-depth interviews were conducted with key stakeholders, including past and current FTI Steering Committee and GPE Board members, GPE Secretariat staff, and a senior development actor who consulted with the GPE on the subject of fragile and conflict-affected states. Each of these interview participants held a senior leadership position within his/her organization, aside from GPE Secretariat staff members, and had worked for many years on issues related to education in fragile and conflict-affected settings. These interview participants were selected from a very small pool due to their highly specialized and unique backgrounds on the intersecting topics of aid to education in contexts of fragility and the history of the Global Partnership for Education, making each respondent uniquely qualified to substantiate, contextualize, and build on information attained through document analysis. Each interview lasted approximately one hour and occurred between November 2013 and August 2014. All interviews were recorded, transcribed, and coded. Our coding strategy was designed to organize interview data into categories (e.g., presence/absence of priority on fragile and conflict settings; GPE mission; funding mechanisms; governance structure; specific conflicts/changing global conflict dynamics) that we predicted, based on our document analysis, would support our understanding of the historical processes of shifts in GPE's strategies and also more specifically experiences in particular countries. Interviews were coded thematically but also temporally in order to categorize interview responses on a timeline of events as we sought to understand the internal and external influences on any described shifts. These interviews, as is common within a process tracing analysis, were meant to corroborate and elaborate on documentary historical evidence. We chose respondents based on their positions as key actors involved with the FTI/GPE and, more specifically, as those who hold knowledge about the organization's history, policies, and country-level processes, which could not be gleaned from documentary sources alone.

\section{Phases of Policy Change: Elevation of Fragile and Conflict-Affected States on the FTI/GPE Agenda}

Since 2011, the Global Partnership for Education has considerably shifted its approach to financing education in fragile and conflict-affected states. According to several interview participants who served on the Board of the FTI Steering Committee or the GPE Board of Directors, the rise of fragile and conflict-affected states on the GPE agenda has been remarkable and, for some, somewhat surprising (Interviews \#1; \#4; \#5; \#6; \#7). The shift in approach has involved three major phases, beginning when the GPE was the FTI and continuing to the present. These phases, which we posit are not distinct but instead overlapping, include: nascent engagement; reflection and revisioning of the role of GPE in investing in fragile and conflict- 
affected settings; and operationalization via changes in governance structure and the development of mechanisms to implement funding in these challenging contexts (see Figure 1).

\subsection{Phase 1: Nascent-Engagement}

The 2002 launch of the Education for All Fast Track Initiative (EFA-FTI) was spearheaded by James Wolfensohn of the World Bank, with the goal of creating a mechanism that would galvanize donor funding to put any developing country with a credible plan on a "fast track" to achieving education for all. The FTI was touted as a multilateral framework that would coordinate donor funds in order to strengthen country-owned education sector plans (Bermingham, 2009; UNESCO., 2010). The FTI was conceived in the context of two important historical moments in global education policy. First was the shape of the development aid architecture, where coordination and harmonization were emerging as central tenets of a growing effectiveness agenda (Savedoff, 2012). Second was increasing global understanding, in the aftermath of the World Education Forum in Dakar, Senegal in 2000, of limited progress toward the EFA goals.

The launch of the FTI coincided with the First High Level Forum on Aid Effectiveness (Rome 2002), where the principles of aid effectiveness were outlined for the first time in a concrete declaration. The Rome Declaration prioritized "good practice standards or principles," where the results of aid investment could be demonstrated ("Rome Declaration on Harmonisation," 2003). Echoing this global priority, countries were evaluated as eligible for FTI funding based primarily on a "gold standard," in other words, a credible Education Sector Plan (ESP) (Cambridge Education, Mokoro, \& Oxford Policy Management, 2010; Dom, 2009; Klees, Winthrop, \& Adams, 2010; Sperling, 2007). The ESP would be judged based upon the FTI's indicative framework - a criteria outline developed from the experiences of "good performers" (Cambridge Education et al., 2010, p. xi). From this assessment, an endorsement had to be made by the local donor group in-country; this group generally included the World Bank, bilateral donors, UNICEF, and the national Ministry of Education. Two financing mechanisms were developed: the Education Programme Development Fund (EPDF) and the Catalytic Fund. The EPDF supported capacity building preceding the receipt of larger funding via the Catalytic Fund (Bermingham, 2009; Berry, 2009; Cambridge Education et al., 2010; Fast Track Initiative, 2009), a mechanism that proved critical for later support to fragile and conflict-affected states. 


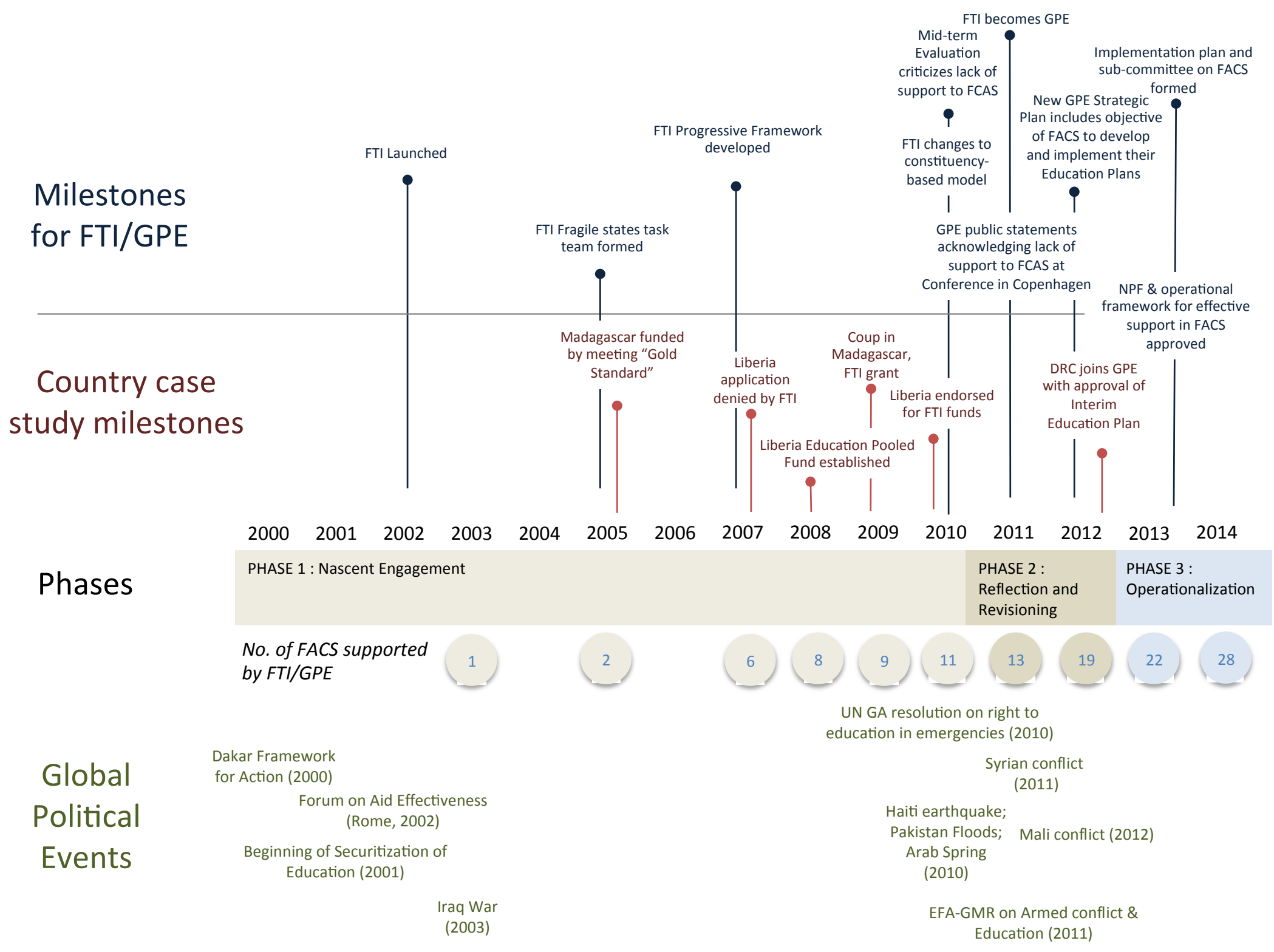


In its first three years, the FTI's agenda did not include any substantive focus on fragile and conflict-affected states. Reflecting increased awareness of the educational needs of children in fragile and conflict-affected settings, as described above, and the acute Iraq war (see Figure 1), the GPE faced "pressure almost from its inception to find a way to meet the needs of fragile states and, in particular, those countries affected by conflict" (Bermingham, 2009, p. 20; Dom, 2009). However, the mechanisms in place were geared not to countries plagued by fragility, but to already "good performers" who were unable to find resources to support their good plans (Berry, 2009). The FTI's framework stressed sound planning, aid efficiency and coordination, sustainable domestic financing, and accountability. A member of the GPE Secretariat described the FTI in the early 2000s as "much more focused on stable countries. Countries where there was a good governance, where there were also a clear political will from the government to invest in education" (Interview \#8). This mandate - to support stability, efficiency and accountability almost necessarily excluded fragile contexts (Dom, 2009).

The launching of the FTI also coincided with a growing acknowledgement in the wider international development arena that, in order to achieve Education for All, mechanisms needed to be in place to finance countries experiencing fragility - including conflict, post-conflict recovery, or natural disaster. The Dakar Framework for Action, which came out of the 2000 World Education Forum, highlighted the ways in which conflict acts as a barrier to education and outlined a commitment to "meet the needs of education systems affected by conflict, national calamities and instability" (UNESCO, 2000, Article 8v). At that time, education in emergency situations became one of nine EFA flagship programs. However, working in fragile and conflictaffected contexts posed an alignment dilemma within "the overarching aid effectiveness agenda" (Dom, 2009, p. 6), as efficient and accountable distribution of aid could not be assured in such settings. In addition, the period after September 11, 2001 represented an increased focus on aid including to education - as a "tool for fighting the war on terror" (Novelli, 2011, p. 50).

Within the FTI, this tension between the goals of aid effectiveness and support to fragile and conflict-affected states resulted in mounting pressure. Members reiterated throughout its early years the crucial need to engage in these challenging contexts, if not prioritize them, citing the fact that very large populations of out-of-school children live in these contexts (Bermingham, 2009, p. 3). In 2005 and 2006, documents drafted following FTI partnership meetings began to include discussions on how to provide resources to "fragile states" and "post-conflict and postdisaster situations" (Bermingham, 2009; Dom, 2009, p. 13). At this time a Fragile States Task Team was formed in order to undertake an exploration of how the FTI could better support countries experiencing fragility and conflict, for instance via the EPDF. Led by Gene Sperling (Director of the Center for Universal Education and the Council on Foreign Relations), a concept paper was developed entitled Closing the Trust Gaps: Unlocking Financing for Education in Fragile States: Recommendations for the FTI Fragile States Task Team, which acted as "an important catalyst for the whole process of expanding financial support to fragile states" (Dom, 2009, p. 17; Sperling, 2007).

In 2007, the FTI Fragile States Task Team developed a "Progressive Framework" that reflected the criteria outlined in the indicative framework, but included more attainable targets for countries experiencing fragility and conflict (Bermingham, 2009; Berry, 2009; Dom, 2009). The 
Progressive Framework aimed to assist countries in developing an FTI Interim Strategy, which could then lead to interim funding. Although in 2008 the FTI Steering Committee agreed to allow an "Interim Status" category for fragile states, the Catalytic Fund would not be modified to support these countries. While the institutional importance of fragile and conflict-affected states was clear, the commitment did not yet allow for engagement. Nevertheless, during the 2009 Catalytic Fund replenishment campaign, discussion of fragile states was prominent (Berry, 2009; Dom, 2009), reflecting broader trends among international actors, including, for example, the 2006 launch of the Education and Emergencies and Post-Crisis Transition (EEPCT) program by UNICEF, the Government of the Netherlands, and the European Commission; the 2007 onset of Save the Children's later annual report, Last in Line, Last in School (Save the Children, 2007), on lack of aid to education in conflict-affected fragile states.

Yet despite rhetorical support and a growing openness to funding fragile states via the FTI, by 2009 it remained unclear how this would happen on any kind of scale. Around this time, the Interim Strategy and Progressive Framework were essentially dropped (Winthrop \& Matsui, 2013). As described by Dom in a working paper to inform an external mid-term evaluation of the Fast Track Initiative: "the issue of how FTI is and should be engaging with fragile states is clearly in a stage of flux" (Dom, 2009, p. 24). The "EFA-FTI Modality Guide" is criticized in the report as treating the fragile states process as "residual" and only vaguely referred to guidelines that had yet to be developed. By 2009, only nine fragile or conflict-affected states were supported by the FTI (Dom, 2009; Fast Track Initiative Secretariat, 2008; Klees et al., 2010; Turrent \& Oketch, 2009).

The 2010 Mid-Term Evaluation cited the FTI's approach to fragile and conflict-affected states as a major shortcoming, citing an overarching tension within educational aid more generally: "'Needs'-based versus 'performance'-based support - i.e. should support go to those countries that are in greatest need, or to those that have demonstrated that they meet key conditions which will allow them to meet their EFA goals? This issue has come to the fore in the FTI's discussion of how to deal with "fragile states"" (Cambridge Education et al., 2010, p. xix). The evaluation noted some progress in making FTI funding more accessible to fragile states, but noted that the "Progressive Framework has not actually been used" (p.52) and "a long process of designing an approach to accommodate fragile states has still not reached fruition and existing proposals are not convincing" (p.83).

The most severe of the criticisms concerning the FTI's engagement with fragile and conflictaffected states attacked the FTI's performance-based support in relying on an endorsement of a credible education plan, widely regarded as a "gold standard." The Mid-Term Evaluation noted:

too strong an emphasis on a 'gold standard' being applied to the ESPs which the FTI endorses. This has gone hand-in-hand with too much emphasis on a one-off endorsement, rather than a continuing relationship of working alongside government through successive cycles of planning and implementation. In turn, this has hindered the adoption of a coherent strategy for addressing the needs of fragile states (Cambridge Education et al., 2010, p. xx). 
This sentiment reflects a swell of criticism occurring at this time which targeted the FTI's emphasis on a credible ESP. Critics drew attention to the likelihood that the design of such plans would require "a high-level of technical capacity and active participation from important stakeholders, which may be difficult to achieve in some less resilient fragile and conflict-affected states" (Klees et al., 2010, p. 8). As described by Bermingham, the FTI presented an unresolved tension between reliance on the gold standard and support to fragile countries "that desperately need assistance but lack the capacity to develop a credible implementation plan" (Bermingham, 2009, p. 21). Both the 2009 and 2010 EFA Global Monitoring Reports arrived at similar conclusions (UNESCO, 2009, p. 227; 2010, p. 18).

Looking back at this time period, interview participants described the on-going misalignment within the FTI. One GPE Board member recalled:

There's a widespread feeling that FTI originally was sort of a funding mechanism for the success stories, countries who had credible plans and who weren't able to mobilize efforts to accelerate those good plans into place. I think there's a recognition that some of the countries which have got the biggest challenges, and actually need the support - if anything even more so - paying attention to that, this is something which emerged... (Interview \#3).

Other Board members concurred that "the FTI as it was, was not fit for purpose" where it was unable to address those countries "that have the most critical needs" (Interview \#6). Exemplifying the problematic features of the FTI's engagement with fragile states were the rejections of particular countries in their application for Catalytic Funding. The application of the Central African Republic was rejected in 2008, as was the application of Liberia in 2007, which is described in more detail below in a case study (Klees et al., 2010; Turrent \& Oketch, 2009).

Related recommendations offered to the FTI concerning support to fragile and conflict-affected states included a need to evaluate progress based not on a firm criteria, but instead on "mutually agreed, context-specific outcomes" (Berry, 2009; Klees et al., 2010, p. 2), and on the need to look beyond governments as partners, including the non-state sector in education delivery (Cambridge Education et al., 2010; Dom, 2009; Klees et al., 2010). On the whole, those advocating for greater support to fragile and conflict-affected states saw the FTI's financing mechanisms as inflexible, and in need of not only improvement, but of a major reform and restructuring. In 2011, when the Education for All Fast Track Initiative was rebranded as the Global Partnership for Education, this restructuring did occur.

\subsection{Phase 2: Reflection and Revisioning}

From the outset of its rebranding as the GPE, there was indication of a revisioning around a needs-based approach to investment decisions, with major implications for the funding of fragile and conflict-affected settings. In discussions of the strategic direction at the first GPE Pledging Conference in Copenhagen in November 2011, significant shortcomings in past methods were acknowledged: "The Global Partnership for Education was slow to recognize the special challenges fragile states face in providing good quality education and in developing a 
comprehensive education sector plan" (Global Partnership for Education, 2011b, p. 23). At this time, failure to address this shortcoming was tied to the overall success of a global mechanism for education aid and thus to the future success of the GPE. The final report of the Copenhagen conference stated:

If the partners in the Global Partnership cannot find more effective ways to help children in fragile states to go to school and learn, it will fail in its objective to support achievement of Education for All... There is a real opportunity to make a difference for children in fragile states if the Global Partnership can get this approach right (Global Partnership for Education, 2011b, p. 18).

The growing consensus on the imperative of addressing the educational needs of fragile and conflict-affected states through the GPE has been reflected in GPE Board meeting discussions, the public profile of GPE, and has culminated in the 2012-2015 Strategic Plan.

Discussions on the topic of fragile and conflict-affected settings have been continuous at GPE Board Meetings. Each meeting of the GPE Board of Directors since 2011 (Paris 2012, Berlin 2012, Kigali 2013, Brussels 2013, and Washington, D.C. 2014) has included at least one presentation and/or Board decision which has been made in reference to supporting fragile and conflict-affected countries. More generally, discussions during Board meetings on the topic of fragile and conflict-affected settings increased notably after the rebranding. Based on an analysis of over 100 meeting documents from Board meetings, an average word frequency analysis by year shows that between 2009 and 2011 - coinciding with the Board restructuring - there was a more than 10-fold increase in the terms "fragile" or "conflict."

The public profile of the GPE has also reflected this rise of fragile and conflict-affected states on the GPE agenda. The new CEO of the GPE, Alice Albright, has made high-profile visits to postconflict GPE countries, such as Democratic Republic of Congo. The GPE website includes a "Focus Area" page on conflict-affected and fragile states, along with several blog posts from experts on fragility and conflict, including Board members, Secretariat staff, and members of the Youth Advisory Group of the UN Secretary General's Education First initiative (Global Partnership for Education, 2014a).

The vision of GPE investment in fragile and conflict-affected settings has moved beyond rhetoric to become codified in the 2012-2015 Strategic Plan. This Strategic Plan identifies as the first of its five objectives "Fragile and Conflict-Affected States Able to Develop and Implement their Education Plans." The Strategic Plan reiterates the critical nature of support to education in fragile and conflict-affected states. The strategy furthermore cites as its third objective "Reaching Every Child: Resources are Focused on the Most Marginalized Children and those in Fragile and Conflict-Affected States" where "In the period covered by this strategic plan, the Global Partnership will focus primarily on fragile and conflict-affected states and gender inequity to get more children into school for a longer and a better education" (Global Partnership for Education, 2012c, p. 14).

\footnotetext{
${ }^{2}$ Instances of "fragile/conflict" rose from $0.13 \%$ coverage in 2009 to $1.36 \%$ coverage in 2011 . The term "conflict" was cross-checked and only those instances relating to conflict-affected states were included. The analysis included similar and stem words (e.g. "fragility")
} 
Decisions over the degree to which the partnership ought to engage in these settings was set in the context of the wider post-Dakar conversation described above, given greater urgency with the approach of the 2015 deadlines for meeting EFA goals and MDG targets. By 2011, when the FTI was rebranded as the GPE, attention to the issue of education in fragility and conflict-affected setting was widespread, both among organizations represented on the GPE Board and among international education development organizations broadly. The broad theme of the 2011 Education for All Global Monitoring Report was The Hidden Crisis: Armed Conflict and Education; the 2011 World Development Report focused on Conflict, Security, and Development; and UNICEF began its large-scale Peacebuilding, Education, and Advocacy Program in 2012. In 2010, the UN General Assembly passed a seminal resolution on the Right to Education in Emergency Situations (United Nations, 2010). The aid community, in general, was grasping the troubling fact that the EFA goals would never be reached without providing context-specific support to fragile and conflict-affected states.

\subsection{Phase 3: Operationalization: Changes in Governance and Funding Mechanisms}

While external normative trends helped to shape the GPE's priorities, there were also important internal shifts. Elements of structure of the GPE allowed the vision to invest in fragile and conflict-affected settings to take hold in a way it had not when it was the FTI. One major overhaul was the nature of its governance, where the FTI Steering Committee was altered to become a Board of Directors. The new constituency-based Board, in response to criticisms that the FTI was essentially a "donor initiative," came to include six seats for donor countries, six seats for developing countries, three seats for multilateral agencies, three seats for civil society organizations, and one seat for the private sector and foundations. ${ }^{3}$ The inclusion of civil society and private foundation actors brought to the Board a deeper experience working in fragile and conflict-affected contexts and a history of campaigning for increased attention to children in fragile settings globally (Interview \#1; Interview \#4). Support to education in these settings was a major policy focus for several organizations and agencies serving on the GPE Board, and the representatives of these organizations on the GPE Board pushed this agenda within the multistakeholder partnership. According to an analysis of key policy documents from each of the GPE Board members and Alternate Board members representing donor, multilateral, civil society and private sector/foundations, 66 percent (16 of 24) explicitly address education in conflict-affected and fragile states as a priority area. This ability to address fragile and conflict-affected states was "one of the key factors" in the restructuring, according to a former Board member (Interview \#6).

Once the new governance structure was determined, particular Board members - who Kingdon would call policy entrepreneurs - began to push fragile and conflict-affected states higher on the GPE agenda. Interview participants agreed that representatives from Save the Children, UNICEF, the Netherlands, and Australia were all highly vocal on this issue since the early GPE Board meetings. In this way, individuals within the GPE, likely both shaping and responding to the wider normative shift, acted to move the issue to the forefront of the partnership. As one member of the FTI Steering Committee stated: "it comes down to individuals" (Interview \#4). Also described as "movers and shakers" (Interview \#5), interview participants mentioned key

\footnotetext{
${ }^{3}$ For a full listing of GPE Board members and alternates see: http://www.globalpartnership.org/board-of-directors
} 
individuals in GPE leadership positions who made clear impressions on Board members in their discussions and presentations on fragile and conflict-affected states, including past CEO Robert Prouty (Interview \#1) and former Board Chair Carol Bellamy, who "really pushed the envelope" (Interview \#5).

Another critical structural shift was in the funding mechanisms themselves. The Strategic Plan identifies the significance of appropriate mechanisms to act on a commitment to investment in fragile and conflict-affected settings. In particular, it focuses on flexibility and context, where " "Business as usual' will not deliver major improvements in fragile states" (Global Partnership for Education, 2012c, p. 23). The document notes that "Although every country context is different, where fragility or conflict exists, the Global Partnership's aim is a sustainable education system that is simple and feasible" (p.22). In 2013, an Implementation Plan was developed to more precisely operationalize the priority areas outlined in the Strategic Plan. A sub-committee was charged with monitoring and advising on the implementation of the objective of investment in fragile and conflict-affected states.(Global Partnership for Education, 2013b, p. $5)$.

There are two specific ways in which the current GPE model supports investment in fragile and conflict-affected settings. First is a revised framework for determining country eligibility and possible financial support for a grant period. This Needs and Performance Framework (NPF) contrasts the earlier "gold standard" advocated during the FTI era, where "Fragility Status" was included as a key consideration (Global Partnership for Education, 2011a, 2012a, 2012b). Second is the Operational Framework for Effective Support in Fragile and Conflict-Affected States, which was approved by the Board of Directors at a 2013 Board meeting in Brussels. This framework encompasses the new approaches and revisions to financing modalities in fragile and conflict-affected states.

The model now supports fragile and conflict-affected countries in developing interim education sector plans, "that covers the most critical activities necessary in the short- to medium- term combined with technical support to help build capacities and vision for the longer term" (Global Partnership for Education, 2011b, p. 25). These "transitional" plans allow countries to build capacity towards a full education plan. The GPE characterized its new approach as "providing greater flexibility in engagement and operations" where, for instance, countries facing emergencies would be permitted to utilize GPE funds to prioritize unanticipated needs, along with "providing the right level of resources over a longer period of time" (Global Partnership for Education, 2011b, 2012c). Moreover, the new approach embodies an appreciation that understanding of the specific country context is crucial, particularly in settings of fragility and conflict. Context-specific benchmarks are allowed under the new flexible model (Global Partnership for Education, 2012a, 2013b). In order to adequately support these countries, engagement on the part of Secretariat staff has been increased, including additional country visits and the hiring of new personnel with expertise in countries experiencing emergencies and conflict (Global Partnership for Education, 2011a, 2012a). As well, the GPE has sought collaborations and consultations with other actors and agencies with focus and expertise on education in fragility and conflict, such as the Inter-Agency Network for Education in Emergencies (Global Partnership for Education, 2012c). 
The rise of education in fragile and conflict-affected states on the GPE agenda was representative of a convergence of factors, including wider normative consensus external to the GPE, the vocal advocacy of individual policy entrepreneurs within the GPE Board, and the development of concrete funding mechanisms appropriate to the contexts. However, the experiences of developing countries are key element to understanding the GPE's increasing support in this area. Below we present three representative case studies that elucidate the GPE's engagement in fragile and conflict-affected states, each providing a context-specific understanding of the GPE's historical and present engagement. First, we describe the case of Liberia, a post-conflict country that encountered difficulties in securing funding from the FTI, shedding light on problematic features of the "gold standard" and paving the way for the GPE's engagement with countries experiencing fragility and conflict. Second, we explore the case of Madagascar, a country that has been funded by the GPE as both a non-conflict and conflict setting, and served as an unplanned pilot for particular funding mechanisms. Third, the Democratic Republic of Congo (DRC) represents a country that would not have been funded under the FTI, but was eligible for GPE funding, and tested the GPE's new approach to supporting countries experiencing conflict and fragility. ${ }^{4}$

\section{Liberia: Paving the way from FTI to GPE}

Liberia's 14-year-long civil war led to a disastrous economic collapse, decimated its infrastructure, and created hundreds of thousands of refugees and internally displaced persons. It is estimated that 70 percent of its schools were either severely damaged or completely destroyed, and during the conflict nearly 50 percent of Liberian children were out of school. A 2003 peace agreement paved the way for successful elections in 2005, resulting in the presidency of Ellen Johnson Sirleaf, who prioritized the return of Liberia's children to school (Government of Liberia, 2007, 2008).

By 2007, education in Liberia was improving, but the many years of conflict had taken its toll on the system. At this time, only 35 percent of schools had latrines, and only 24 percent of students at the primary level had a desk and chair. A very large school enrolment increase since 2005 had the adverse impact of burdening already poorly-resourced schools, and schools generally had to charge fees to parents, which contributed to a high drop-out rate. Overall, the quality of education in Liberia was deemed extremely poor (Government of Liberia, 2007, 2008, 2010).

Liberia's 2007 application for Catalytic Funding from the Fast Track Initiative therefore came at a crucial time for the country, when its education system was in desperate need of resources in order to meet demand and increase quality. In applying for support to its Liberian Primary Education Recovery Program (LPERP), the Government requested funding for a broad 3-year strategic plan "aimed at putting primary education back on track after years of functioning on an ad-hoc emergency basis following the end of the civil war in 2003" (Government of Liberia, 2007 , p. 5). The Liberian government requested $\$ 70.6$ million from the FTI to support a range of needs, including infrastructure, curriculum development, teacher training, and organizational

\footnotetext{
${ }^{4}$ The cases have been chosen based on their characteristics as different historical exemplars for GPE engagement. Our cases are geographically clustered in Africa due to the fact that 25 of the 28 fragile and conflict-affected GPE developing countries are in sub-Saharan Africa.
} 
capacity building (Government of Liberia, 2007, p. 9; Inter-Agency Network for Education in Emergencies, 2011).

While the country met all eligibility requirements for FTI Catalytic Funding, its application was unsuccessful. Eligibility meant that Liberia met benchmarks such as: public revenues as a percentage of GDP; education expenditures as a percentage of the national budget; primary education expenditures as percent of education budget; first grade intake rates; primary completion rates ; pupil-teacher ratio; average annual teacher salary as a multiple of GDP per capita; annual number of hours of instruction; and proportion of girls and boys demonstrating sufficient reading fluency and comprehension after two years of education and at the end of primary school (Education For All Fast Track Initiative, 2004, p. 15; Klees et al., 2010, p. 3). Despite meeting these requirements, the Catalytic Fund Committee denied funding to Liberia due to gaps in data, accountability concerns, low management capacity, and fiduciary risk. Moreover, Liberia was seen as lacking a comprehensive Education Sector Plan - a key requirement for FTI approval (Bermingham, 2009; Klees et al., 2010; Schmidt \& Taylor, 2010, Interview \#2). As the Government of Liberia describes: "This put the LPERP implementation at risk because of serious funding constraints" (Government of Liberia, 2010, p. 30).

Noting the urgency of the Liberian education context, where an already fragile system could likely not improve beyond its already bleak state without external funding, other actors stepped in to aid the country. UNICEF, the Government of the Netherlands (who sat on the Catalytic Fund Committee), and the Open Society Institute together established the Liberia Education Pooled Fund (EPF) (Klees et al., 2010; Schmidt \& Taylor, 2010, Interviews \#2; \#5; \#6). By March of 2009, as a transitional funding mechanism and with relatively fast disbursement, the EPF had supported key activities, including textbook provision, construction of 40 new schools, and the establishment of teacher training institutes. Moreover, the EPF acted as a catalyst for the Education Sector Development Committee (ESDC) in Liberia, which operated as a country-level forum on education sector issues, combining educational stakeholders including representatives from in-country donor partners, local government, local civil society groups, and international non-governmental organizations (Government of Liberia, 2010; Schmidt \& Taylor, 2010, Interview \#2). The Liberia Education Pooled Fund, by acting in a situation where the FTI did not, acted as a case of policy entrepreneurship in this space, demonstrating to the FTI and its Steering Committee the possibilities for its own involvement.

In 2009, the Government of Liberia developed a comprehensive Education Sector Plan outlining several priorities and the intention to re-apply for Catalytic Funding from the FTI is outlined in the ESP (Government of Liberia, 2010, p. xviii). In 2010 Liberia was endorsed by the FTI and funding was approved in the amount of $\$ 40$ million, as its ESP was recognized as "achievable, credible and financially sustainable" (Fast Track Initiative, 2010, p. iv). The preparation of the ESP and its approval is widely acknowledged as a success of the EPF, which enabled capacity to draft the plan (Fast Track Initiative, 2010, Interview \#6).

The case of the GPE and earlier FTI engagement with Liberia is significant for several reasons. First, the EPF was in large part a result of the coming together of public and private sector funders, as it included as a key partner the Open Society Institute. As a public-private partnership, the EPF, which enabled Liberia to secure funding from the GPE, has been viewed as 
"particularly timely as an increasing number of private foundations are committing significant funds to various initiatives for education reform in developing countries" (Schmidt \& Taylor, 2010, p. 19). And coinciding with Liberia's grant approval was the major FTI/GPE governance restructuring, which came to include private foundations on the Board of Directors. The Open Society's participation in the EPF reportedly highlighted the value of a foundation and the capacity private foundations could bring to the GPE Board (Interview \#4; Interview \#6). The EPF furthermore shed light on the value and efficiency of a pooled educational fund in a fragile context. As the Liberian government describes in its ESP: "The EPF is a model for a transitional modality for delivering education aid to a post-conflict country" (2009, p.30-31). The EPF provides a case of a pooled funding mechanism that was coordinated and harmonized, and dispersed funds relatively efficiently (Klees et al., 2010; Schmidt \& Taylor, 2010).

While not a unique example, the ESDC in Liberia was one of a few exemplars for a countrylevel Local Education Group, which as of the GPE restructuring is now a requirement within any GPE recipient country. In Liberia, the ESDC continues to operate as a forum for donor partners, civil society and government actors to coordinate and communicate on issues that go well beyond the GPE funding (Interview \#2). The stipulation that GPE developing countries must have a LEG is supported by models like the Liberia ESDC.

Finally, and most importantly, Liberia's initial denial drew attention to major shortcomings of the FTI's funding mechanisms, where a post-conflict country lacked the capacity to fulfill the "gold standard" of designing a comprehensive Education Sector Plan. The FTI partners felt they were constrained by the funding criteria. As a former Board member explained of the Liberia case: "I think it sort of pushed the FTI to - for lack of a better term - sort of a crisis of conscience of saying, we can't help a country like Liberia. And at that time you remember Ellen Johnson Sirleaf had just come into her administration, started in 2006. Liberia was very much at the height of the potential African success story, a post-conflict success story that everybody wanted to help. They [FTI] felt quite guilty essentially that they couldn't" (Interview \#6). A GPE Secretariat staff member similarly stated: "So they needed help, they just came out of war, they've just gotten a new president. They've got a real political will to do something yet they couldn't be eligible because of the criteria of the FTI" (Interview \#8). Another interview participant proposed that the altered funding mechanisms gave Liberia "an opportunity" that it otherwise would not have had (Interview \#2). The rejection of Catalytic Funding for Liberia in part set in motion a major self-reflection for the FTI, and "The rejection... was a turning point in the need to define a way of expanding FTI support to fragile states" (Turrent \& Oketch, 2009, p. $362)$.

\section{Madagascar: Piloting Engagement in Fragile and Conflict-Affected Settings}

Madagascar has experienced periods of both stability and conflict over the past decade. In the midst of an economic renaissance in the early 2000s, fueled by large amounts of development aid and increasing economic investment, a military-backed coup d'état in 2009 ousted then-President Marc Ravalomanana creating great instability in the country. Poverty skyrocketed rapidly and the percentage of the population living on less than $\$ 2$ a day went from 69 percent in 2008 to 92 percent in 2012 (Ross \& Rijasolo, 2013). The education sector was deeply affected. While the primary school completion rate in Madagascar had increased from 63 percent in 2007 to 76 
percent in 2009, it then fell to 72 percent in 2011 in the aftermath of the coup (Global Partnership for Education, 2014b).

Madagascar was first funded in 2005 by the FTI, after the approval of its Education For All Education Sector Plan. At that time, it met all of the eligibility criteria - the "gold standard" - as outlined in the FTI Indicative Framework described above. Until 2009, Madagascar was making great progress in meeting the goals of the FTI-funded ESP, particularly related to primary school enrollment and recruitment and training of teachers (UNICEF Madagascar, 2012, pp. 7-8)

After the 2009 coup, a de facto government took power, the Haute Autorite pour la Transition (HAT). This government was not recognized by the international community, violating the principles of FTI investment and making it impossible for the FTI and subsequently the GPE to continue operating as before in Madagascar. The budget of the Ministère National d'Education (MNE) decreased by 25 percent between 2008 and 2011 (UNICEF Madagascar, 2012, p. 16), resulting in massive declines in enrolment, completion, and payment of teachers salaries. Between 2008 and 2011, the country fell 15 places on Transparency International's Corruption Perceptions Index. Madagascar was out of compliance with the FTI Indicative Framework. This case provided an unplanned "pilot" of sorts in which the FTI continued to engage with a country despite the challenging circumstances. A FTI grant of US\$64 million was made in 2009. This grant allowed for the continued involvement and coordination of key education sector partners and guaranteed core funding to education at a time of budget volatility (Global Partnership for Education, 2013c).

There were two main shifts in the FTI/GPE support to Madagascar before and after 2009. First was in the nature of what was funded. This period was characterized by lack of coherence in sector plans (UNICEF Madagascar, 2012, pp. 8, 17). In this situation, rather than funding an Education Sector Plan, the 2009-2011 FTI grant funded a series of activities, primarily for the construction of schools and the payment of teachers' salaries. Then, a smaller grant from the GPE in 2012 funded the development of an Interim Education Sector Plan. This plan - which sets out a strategy for rebuilding Madagascar's planning and management capacity - was finalized in 2012 and approved by the Local Education Group in February 2013 (Madagascar Groupe Local des Partenaires de l'Education, 2013). Just as was done later in DRC (see below), the IEP then served as the basis for a larger GPE grant of US $\$ 85.4$ million approved in early 2013 (Global Partnership for Education, 2013c, p. 38). This grant includes the goal of development of full ESP by 2015.

The second shift in FTI/GPE support to Madagascar was in the funding modality. Given that the government was unrecognized, FTI and then GPE needed a mechanism through which to disperse and manage funds. In this case, they developed the precursor to what would later be called the "Managing Entity" (ME), a role that UNICEF took on after 2009 and until 2011, at which point the national government was recognized and UNICEF was converted into a more traditional "Supervising Entity (SE)." While the modality of a ME was not common operating procedure for the FTI or for the early GPE, it is a key feature of the 2013 GPE Operational Framework for Effective Support in Fragile and Conflict-Affected States, aimed at improving its flexibility and effectiveness in fragile and conflict-affected environments (Global Partnership for Education, 2013d). 
A Supervising Entity is defined as "any GPE multilateral agency partner or GPE donor country partner designated to receive transferred funds and supervise an activity" (Global Partnership for Education, 2012e). In the majority of cases, the SE is the World Bank (Global Partnership for Education, 2013a). Under this arrangement, the principle of country ownership (Global Partnership for Education, 2013b, p. 4) is upheld, as funds are managed by national governments. However, one of the central decisions about how best to support fragile and conflict-affected contexts was to determine the best ways to "manage and mitigate risks" (Global Partnership for Education, 2013b, p. 3), especially in the management of the funds. As an alternative to a Supervising Entity, in a situation where the government does not have the capacity to implement GPE (or FTI) funding, as in Madagascar of 2009-2011, a Managing Entity model can be employed temporarily. A Managing Entity (ME) is a nongovernment actor, that receives "transferred funds and implement activities in support of the government's education plan" (Global Partnership for Education, 2012d).

\section{DRC: Testing Processes of Approval and Funding Modalities}

The Democratic Republic of Congo (DRC) is a country both fragile and conflict-affected. Ongoing conflicts since the early 1990s resulted in more than 5 million deaths and more than 2 million people displaced. Over the 1990s and 2000s, there was massive under-investment in the education system to the point of its near collapse. The World Bank noted that a key feature of the education system in DRC was the "almost complete lack of government provision and financing of all levels of education, including the primary level" (2005, p. xiv). Spending per pupil per year fell 96 percent, from US\$109 in 1980 to US\$4 in 2002 (AfriMAP \& Open Society Initiative for Southern Africa, 2009, p. 2). Parents have had to shoulder a large share of education costs in the form of substantial school fees. In 2008, Gross Enrollment in primary school was 47 percent, and much lower in conflict-affected regions (UNESCO, 2011, pp. 135, 308). Another key feature of the education system in DRC is its dual nature: of the 10.6 million pupils nationwide in 2012, 72 percent attended schools managed by religious communities (Democractic Republic of Congo, 2012, p. 7).

DRC applied to the GPE for funding in 2012. It would not have been funded under the FTI eligibility requirements. The cases of Liberia and Madagascar, however, paved the way for approval under the GPE. The need was clear: only 59 percent of pupils completed primary school (Democractic Republic of Congo, 2012) and there were 3.5 million children of primary age out of school (Global Partnership for Education, 2013c, p. 30). Like Liberia, however, there were issues related to data, accountability, management, and risk, which meant that DRC would not have met the "gold standard" as set out by the FTI. For example, the UNESCO Institute for Statistics does not report education statistics for DRC due to "inconsistencies identified in the UN Population Division population estimates... for the primary and lower secondary school-age population" (UNESCO Institute of Statistics, 2013). Overall governance indicators also pointed to investment risk: DRC ranked 154 out of 177 countries globally on Transparency International's Corruption Perceptions Index (Transparency International, 2013), and the World Bank's Worldwide Governance Indicators show DRC to be at the tenth percentile or below of all countries for all six of the governance indicators (World Bank, 2013). 
DRC, however, has benefited from path set forward by the Liberian and Malagasy experience. DRC was able to join the Global Partnership for Education (GPE) in June 2012 following a positive appraisal and endorsement of its Interim Education Plan (IEP) 2012-2014 by the Partenaires Technique et Financiers en Education (PTF-E) (Srtruye de Swielande, 2012). This was the first ever Education Sector Plan in DRC (Global Partnership for Education, 2013c, p. 31) and, according to a staff member of the GPE Secretariat, "demonstrated real political will [by the DRC government] to rebuild its education system, most notably through increasing budgetary allocations to the sub-sector (primary and secondary education) from 9.2 percent in 2011 to 15 percent by 2015" (Interview \#8).

The requirement for a transitional education plan rather than a fully developed ESP embodied the GPE principle of "progressivity" and foreshadowed the 2013 GPE Operational Framework for Effective Support in Fragile and Conflict-Affected States. As the World Bank noted in the Project Appraisal Document, an IEP was the appropriate mechanism for "accelerating the achievement of universal primary education" without "waiting for the completion of a holistic strategy for the entire education sector (to include higher education, adult literacy and nonformal education)" (World Bank, 2012, p. 8). The very process of creating an IEP "fostered education sector coordination by encouraging regular meetings of the LEGs, Joint Sector Reviews, and the inclusion of civil society" (Global Partnership for Education, 2013d). A GPE Secretariat staff member described the new coordination between national and international education stakeholders in DRC, writing: "The commitment from both the Government and the local partners has created momentum and represents a real opportunity for substantial progress in the education sector" (Personal communication, 27 May 2014).

The GPE had a choice to make in the modality for implementation of the GPE funds. Unlike in Madagascar, the mechanism of choice for the implementation of funds was through a Supervising Entity, the World Bank. A Managing Entity model may have allowed for more flexibility in supporting existing educational initiatives of NGOs and religious organizations, operating in areas where the government was unwilling to do so. In choice of modality - as well as content - for the GPE grant to DRC, there were trade-offs between short-term flexibility and feasibility and long-term capacity building and sustainability. The program activities of the DRC IEP were directly aligned with the priorities of the GPE of accelerating progress towards universal primary education for all children - especially the most marginalized, including girls and those affected by fragility and conflict - and improving the quality of learning. The World Bank noted in the Project Appraisal Document, however, the necessary balance in "support to post-conflict/fragile countries ... between essential inputs to address urgent needs (construction, textbooks, teachers' training) and reform interventions (restructuring of the administrative offices, assisting SECOPE [Central Office for Teachers Salaries and Monitoring]) to progressively establish a foundation for further systems with a better accountability (World Bank, 2012, p. 20). The funding modality itself seeks a similar balance. It was project funding, which is true of 85 percent of GPE grants in fragile and conflict-affected settings and 79 percent of other settings (Global Partnership for Education, 2013e, pp. 49-50). The coordination structure, however, was designed so that the GPE-supported projects and partner activities worked toward capacity strengthening of the MEPSP with the goal of laying the foundation for transition to a pooled-funding mechanism in the short- to medium-term. 


\section{Discussion and Conclusions}

Our study examined how the GPE has shifted its course and thereby strengthened its response to a major policy issue in the arena of education and development. In light of our conceptual framework, we posit that three sources of change have engendered the GPE's shifting policies on supporting fragile and conflict-affected states. First, GPE's nascent stage of engagement was predated by a broad normative shift in the wider development arena. Actors ranging from bilateral aid agencies to civil society organizations contributed to widespread problem recognition by drawing attention to the urgent need to better support education in countries experiencing fragility and conflict. Evidence was mounting to show that EFA goals could not be reached without addressing these complex contexts, forcing development actors to recognize education in fragile contexts as a critical problem.

Second, and as a result, groups of actors as well as individuals began to push the issue of fragile and conflict-affected states up the agenda from both outside and inside their own organizations. The rise of the issue within GPE was fostered via advocacy on the part of individual policy entrepreneurs, including senior GPE Secretariat staff members, who were also responding to the normative shifts in the wider development arena. The FTI and the GPE, as a multi-stakeholder partnership, was a space in which multiple actors brought their commitments on this issue to the forefront. Moreover, those within the GPE suggested that if the organization - with its mandate for education development and assisting those children most in need - had ignored this normative shift and not adequately responded to the growing consensus in the wider development community, it could have damaged its own legitimacy. These policy entrepreneurs helped to instigate, sustain, and solidify the GPE's work in this area.

Finally, structural changes in the global policy environment - specifically globalization forces that pushed global governance models to include private and civil society actors - spurred organizational changes to the Board of the GPE. Our research has shown that non-state sector actors on the GPE Board were also policy entrepreneurs who contributed to problem recognition and highlighted normative shifts concerning education in fragile and conflicted-affected states.

Through a rigorous examination of historical drivers, this study has presented a case where an international organization has shifted its bureaucratic practices, organizational structure, and policy course as a result of both exogenous and endogenous forces. These changes have in turn led to what we propose to be a strengthened and more context-specific support to education in countries experiencing various degrees of fragility, as shown in the three case studies.

External critics from the fields of development and education have already begun to tout the GPE as a possible model to emulate in the way that the unique needs of fragile and conflictaffected states have been internalized by the organization's policies (Dryden-Peterson, Forthcoming; Rose \& Steer, 2013; Winthrop \& Matsui, 2013). The revised GPE financing approach has indeed facilitated a notable rise in GPE developing country partners that are classified as fragile and conflict-affected. The GPE now supports 28 settings of fragility and conflict such as those in-conflict (e.g., Somalia), post-conflict (e.g., Liberia), and emergency 
(e.g., Central African Republic) settings. As a former GPE Board member explains, engaging with fragile and conflict-affected settings presents a major shift: "it's a long road still left to go but the fact that we're even having a conversation about the Central African Republic when three years ago you couldn't even figure out how to get money to post-conflict countries - and now we're discussing how do we address immediate needs in countries that are currently in conflict" (Interview \#6).

Despite the changes identified in this study, challenges remain for the GPE in its work in fragile and conflict-affected settings and more broadly. The GPE has been subject to well-grounded criticism, including of its dependent relationship to the World Bank, the agency that acts as its physical "host" and serves the role of Supervising Entity in the majority of GPE recipient countries. In response to this criticism, the GPE commissioned an external review of its hosting relationship with the Bank. The two organizations, however, remain closely tied, begging questions concerning the autonomy of the GPE to function as a partnership of stakeholders in light of the World Bank's influence (Global Campaign for Education, 2012).

Moreover, the GPE is critiqued by some for its lack of attention to learning goals and for falling short of its initial financing targets. Particularly in light of recent bilateral reductions in aid to education, GPE funding is arguably very weak compared to what is needed to provide quality education for all globally, including in settings of fragility and conflict. At its most recent replenishment event, GPE bilateral donors pledged less than targeted, calling into question the efficacy of the organization to truly "galvanize" actors to improve education (McCracken, 2014; Schemo, 2014).

These broad critiques bear significance for education in contexts of fragility and conflict as they present potentially serious limitations for the extent to which the GPE can truly spur and maintain global financing to education more generally and for its ability to function as a partnership with equal voice to all stakeholders. Our research recognizes these important criticisms whilst we focus on shifts in GPE policy relating specifically to fragile contexts which we maintain have been sizable and worthy of close attention. We focus on the GPE as an example for a distinct policy area and, in this sense, we posit that the GPE has made noteworthy strides. The GPE's ability to maintain this momentum on supporting education in contexts of conflict and fragility will depend on if and how it responds to these wider criticisms.

A more specific challenge relating to the GPE's commitment to fragile and conflict-affected states concerns the needs of countries experiencing acute crisis, characterized by high levels of violence, including for civilians; destruction of infrastructure; and mass displacement. The number of children living in these contexts has escalated in recent years, with the number of refugees, for example, reaching levels not seen since World War II and 10.7 million people newly displaced in 2014 - the largest scale of displacement ever recorded (UNHCR, 2014a; United Nations, 2014). At the same time, funding for education accounted for only 2 percent of all humanitarian funding in 2013 (Carfax Education, 2013). A Secretariat member described how current shifts in understanding the nature of global educational need has again prompted the GPE Board to consider the mechanisms by which it could engage in a new context: acute humanitarian emergencies (Interview \#8). As an example, despite the immense educational 
needs of Syrian refugees in Lebanon, the GPE is unable to engage because Lebanon is not qualified to be a GPE recipient country due to its middle-income status.

In late 2013 through mid-2014, the GPE Policy and Strategy Committee prepared a document outlining a policy framework for the GPE role in these contexts, which was discussed at length at the June 2014 Board Meeting in Brussels. The framework suggests three possible and nonmutually-exclusive roles for the GPE: advocacy, coordination, and financing. The framework opens the possibility that GPE could engage in advocacy and coordination even in non-GPE countries and in GPE countries that are not eligible for Program Implementation Grants (Global Partnership for Education, 2014d, p. 6). The adoption of policies and creation of mechanisms to expand GPE support to acute emergency contexts would represent a fourth phase in the GPE's evolving support to fragile and conflict-affected settings

Looking forward in terms of both the GPE's evolving policy agenda and, as well, a future research agenda, it is important to examine the implementation of the policies we have outlined in this study at the country-level. In this endeavor, it will be critical to revisit the goals outlined by the GPE itself. For instance, has the GPE been successful in its strategic objective of aiding fragile and conflict-affected countries in implementing their own education sector plans? And, has the GPE's engagement in fragile states helped it to achieve its overarching aim to increase access to education for all children, and enable them to learn?

\section{Acknowledgements}

We are grateful to Alvine Sangang and Mialy Clark for their valuable research assistance.

Appendix A: Key Documents Analyzed ${ }^{5}$

\begin{tabular}{|l|l|l|l|}
\hline Date & Title & Location & Type of Document \\
\hline EFA/FTI or GPE Produced Documents & Framework \\
\hline 2004 & $\begin{array}{l}\text { Accelerating progress } \\
\text { towards quality universal } \\
\text { primary education }\end{array}$ & Washington, DC & \\
\hline 2008 & $\begin{array}{l}\text { The Road to 2015: Reaching } \\
\text { the Education Goals }\end{array}$ & Washington, DC & Annual report \\
\hline 2009 & $\begin{array}{l}\text { Education For All Fast Track } \\
\text { Initiative: Annual Report } \\
\text { 2009 }\end{array}$ & Washington, DC & Annual report \\
\hline 2012 & $\begin{array}{l}\text { Guidelines for effective } \\
\text { engagement in Conflict- } \\
\text { Afflicted Contexts }\end{array}$ & Washington, DC & Board meeting document \\
\hline 2012 & $\begin{array}{l}\text { Needs and Performance } \\
\text { Framework for Education }\end{array}$ & Washington, DC & Brochures and Factsheet \\
\hline 2012 & $\begin{array}{l}\text { Strategic Plan 2012-2015 } \\
\text { Consolidated Quarterly } \\
\text { Financial Report for the } \\
\text { Quarter Ending December 31 } \\
\text { 2013 }\end{array}$ & Washington, DC & Governance report \\
\hline
\end{tabular}

${ }^{5}$ All document published before 2011 authored by Education for All Fast Track Initiative; after 2011 authored by Global Partnership for Education

${ }^{6}$ As categorized in GPE online library 


\begin{tabular}{|c|c|c|c|}
\hline 2013 & $\begin{array}{l}\text { GPE Operational Framework } \\
\text { for Effective Support in } \\
\text { Fragile and Conflict-Affected } \\
\text { States }\end{array}$ & Washington, DC & Country guidelines \\
\hline 2013 & $\begin{array}{l}\text { How the Global Partnership } \\
\text { for Education Adds Value }\end{array}$ & Washington, DC & Replenishment document \\
\hline 2013 & $\begin{array}{l}\text { In Focus : GPE in Fragile and } \\
\text { Humanitarian }\end{array}$ & Washington, DC & Brochures and Factsheet \\
\hline 2013 & $\begin{array}{l}\text { Results for Learning Report } \\
\text { 2013: Facing the Challenges } \\
\text { of Data, Financing, and } \\
\text { Fragility. }\end{array}$ & Washington, DC & Progress report \\
\hline 2014 & $\begin{array}{l}\text { Policy Framework on the } \\
\text { Global Partnership's Role in } \\
\text { Humanitarian and Complex } \\
\text { Emergency Contexts. }\end{array}$ & Washington, DC & Board meeting document \\
\hline 2014 & $\begin{array}{l}\text { Principles and Options for } \\
\text { the Revision of the Global } \\
\text { Partnership for Education } \\
\text { Funding Model }\end{array}$ & Washington, DC & Board meeting document \\
\hline 2014 & $\begin{array}{l}\text { Second Replenishment } 2015 \\
\text { to 2018: 250Million Reasons } \\
\text { to Invest in Education, The } \\
\text { Case for Investment }\end{array}$ & Washington, DC & Replenishment document \\
\hline \multicolumn{4}{|c|}{ Board of Directors Meeting Reports } \\
\hline 2011 & Board of Directors Meeting & Kigali, Rwanda & Board meeting document \\
\hline 2011 & $\begin{array}{l}\text { Pledging Conference } \\
\text { Summary Report }\end{array}$ & Copenhagen, Denmark & Board meeting document \\
\hline 2012 & $\begin{array}{l}\text { Report of the Meeting of the } \\
\text { Board of Directors }\end{array}$ & Berlin, Germany & Board meeting document \\
\hline 2012 & $\begin{array}{l}\text { Report of the Meeting of the } \\
\text { Board of Directors }\end{array}$ & Paris, France & Board meeting document \\
\hline 2013 & $\begin{array}{l}\text { Report of the Meeting of the } \\
\text { Board of Directors }\end{array}$ & Brussels, Belgium & Board meeting document \\
\hline 2013 & $\begin{array}{l}\text { Report of the Meeting of the } \\
\text { Board of Directors }\end{array}$ & Addis Ababa, Ethiopia & Board meeting document \\
\hline 2014 & $\begin{array}{l}\text { Report of the Meeting of the } \\
\text { Board of Directors }\end{array}$ & Washington, DC & Board meeting document \\
\hline
\end{tabular}

Source: http://www.globalpartnership.org/board-of-directors 


\section{References}

AfriMAP, \& Open Society Initiative for Southern Africa. (2009). The Democratic Republic of Congo: Effective Delivery of Public Services in the Education Sector. Johannesburg, South Africa: AfriMAP and The Open Socoety Initiative for Southern Africa.

Ball, Stephen. (2012). Global Education Inc. New Policy Networks and the Neo-Liberal Imaginary. Abingdon: Routledge.

Barkin, S. (2006). International organization: Theories and institutions. New York: Palgrave Macmillan.

Bennett, Andrew. (2010). Process tracing and causal inference. In H. Brady \& D. Collier (Eds.), Rethinking Social Inquiry. Lanham, MD: Rowman and Littlefield.

Bermingham, Desmond. (2009). Scaling up aid for education. Lessons from the Education for All Fast Track Initiative (FTI) Background paper prepared for the Education for All Global Monitoring Report 2010. Paris: UNESCO.

Berry, C. (2009). A Framework for Assessing the Effectiveness of the Delivery of Education Aid in Fragile States. Journal of Education for International Development, 4(1), 1-12.

Burnside, C., \& Dollar, D. (2000). Aid, policies and growth. American Economic Review, 90(4), 847-868.

Cambridge Education, Mokoro, \& Oxford Policy Management. (2010). Mid-Tem Evaluation of the EFA Fast Track Initiative, Final Synthesis Report Volume 1--Main Report. Cambridge: Cambridge Education, Mokoro, \& Oxford Policy Management.

Campbell, J.L. (1998). Institutional analysis and the role of ideas in political economy. Theory and Society, 27(3), 377-409.

Campbell, J.L. (2002). Ideas, politics, and public policy. Annual Review of Sociology, 28, 21-38.

Campbell, J.L. (2007). Institutional reproduction and change. In G. Morgan, J. Campbell \& O. K. Peterson (Eds.), The Oxford Handbook of Comparative Institutional Analysis. Oxford: Oxford University Press.

Carfax Education. (2013). Education Cannot Wait: Financing Education in Emergencies, Challenges and Opportunities. Geneva: Global Education Cluster.

Collier, David. (2011). Understanding process tracing. Political Science and Politics, 44(4), 823-830. 
Democractic Republic of Congo, MEPSP. (2012). Global Partnership for Education Program Implementation Grant. Washington, DC: Global Partnership for Education.

Dom, C. (2009). FTI and Fragile States and Fragile Partnerships. from http://www.cambed.com/fasttrackinitiative/download/WP6-FTI FragileStates 9Jan09.pdf.

Dryden-Peterson, Sarah. (Forthcoming). Policies for education in conflict and post-conflict reconstruction. In K. Mundy, A. Green, R. Lingard \& A. Verger (Eds.), Handbook of Global Policy-Making in Education. Chichester, UK: Wiley-Blackwell.

Education For All Fast Track Initiative. (2004). Accelerating progress towards quality universal primary education: Framework. Washington, DC: Education For All Fast Track Initiative.

Fast Track Initiative. (2009). Education For All Fast Track Initiative: Annual Report 2009. Retrieved from http://documents.worldbank.org/curated/en/2009/12/16818691/educationall-fast-track-initiative-annual-report-2009. website:

Fast Track Initiative. (2010). Appraisal of the 2010-2020 Education Sector Plan of Liberia. from https://http://www.globalpartnership.org/download/file/fid/2832.

Fast Track Initiative Secretariat. (2008). The Road to 2015: Reaching the Education Goals. Washington, DC: Fast Track Initiative.

Global Campaign for Education. (2012). A more ambitious, effective Global Partnership for Education: Three priorities for the next phase of reform. from http://www.campaignforeducation.org/en/news/global/view/112-a-more-ambitiouseffective-global-partnership-for-education-new-briefing-by-civil-society-organisations

Global Partnership for Education. (2011a). EFA FTI Strategy for Fragile States for Decision. Washington, DC.

Global Partnership for Education. (2011b). Pledging Conference Outcomes Report. Retrieved August 1, 2014, from https:/http://www.globalpartnership.org/download/file/fid/3432.

Global Partnership for Education. (2012a). Guidelines for effective engagement in ConflictAfflicted Contexts. from http://www.globalpartnership.org/content/guidelines-effectiveengagement-fragile-and-conflict-affected-contexts.

Global Partnership for Education. (2012b). Needs and Performance Framework for Education. from https:/http://www.globalpartnership.org/content/needs-and-performanceframework-education-plan-implementation-grants.

Global Partnership for Education. (2012c). Strategic Plan 2012-2015. Washington, DC: Global Partnership for Education. 
Global Partnership for Education. (2012d). Terms of Reference for Managing Entities. Washington, DC: Global Partnership for Education.

Global Partnership for Education. (2012e). Terms of Reference for Supervising Entities. Washington, DC: Global Partnership for Education.

Global Partnership for Education. (2013a). Consolidated Quarterly Financial Report for the Quarter Ending December 31 2013. Washington, DC: Global Partnership for Education.

Global Partnership for Education. (2013b). GPE Operational Framework for Effective Support in Fragile and Conflict-Affected States. Washington, DC: Global Partnership for Education.

Global Partnership for Education. (2013c). How the Global Partnership for Education Adds Value. Washington, DC: Global Partnership for Education.

Global Partnership for Education. (2013d). In Focus : GPE in Fragile and Humanitarian Contexts. Washington, DC: Global Partnership for Education.

Global Partnership for Education. (2013e). Results for Learning Report 2013: Facing the Challenges of Data, Financing, and Fragility. Washington, DC: Global Partnership for Education.

Global Partnership for Education. (2014a). GPE Blog. from http://www.globalpartnership.org/blog

Global Partnership for Education. (2014b). Madagascar. Retrieved 18 August 2014, 2014, from globalpartnership.org/country/madagascar

Global Partnership for Education. (2014c). Policy Framework on the Global Partnership's Role in Humanitarian and Complex Emergency Contexts. Washington, DC: Global Partnership for Education.

Global Partnership for Education. (2014d). Principles and Options for the Revision of the Global Partnership for Education Funding Model. Washington, DC: Global Partnership for Education.

Global Partnership for Education. (2014e). Second Replenishment 2015 to 2018: 250Million Reasons to Invest in Education, The Case for Investment. Washington, DC: Global Partnership for Education.

Government of Liberia. (2007). Liberian Primary Education Recovery Program. from http://planipolis.iiep.unesco.org/upload/Liberia/Liberia_plan.pdf.

Government of Liberia. (2008). Poverty Reduction Strategy. from http://www.imf.org/external/pubs/ft/scr/2008/cr08219.pdf. 
Government of Liberia. (2010). Education Sector Plan. from https://http://www.globalpartnership.org/content/liberia-education-sector-plan.

Hall, P.A. (2010). Historical institutionalism in rationalist and sociological perspective. In J. Mahoney \& K. Thelen (Eds.), Explaining institutional change: Ambiguity, agency. Power. Cambridge: Cambridge University Press.

Hefler, L. (2006). Understanding change in international organizations: Globalization and innovation in the ILO. Vanderbilt Law Review, 59, 649.

INEE. (2004). Minimum Standards for Education in Emergencies, Chronic Crises and Early Reconstruction. Paris: UNESCO.

INEE. (2010). Minimum Standards for Education: Preparedness, Response, Recovery. New York: INEE.

Inter-Agency Network for Education in Emergencies. (2011). Education and Fragility in Liberia. from http://unesdoc.unesco.org/images/0021/002121/212197e.pdf.

Kapur, D. (2000). Process of Change in International Organizations. Cambridge, MA: Weatherhead Center for International Affairs, Harvard University.

Kingdon, John W. (2011). Agendas, alternatives, and public policies (Updated 2nd ed.). Boston: Longman.

Klees, Steven J., Winthrop, Rebecca, \& Adams, Anda. (2010). Many Paths to Universal Primary Education: Time to Replace the Indicative Framework with a Real Country-Driven Approach Brookings Global Economy and Development Global Views. Washington, DC: Brookings.

Madagascar Groupe Local des Partenaires de l'Education. (2013). Madagascar Plan Interimaire de l'Education (2013-2015), Lettre d'endossement par les membres du groupe local des partenaires de l'education. Antananarivo: Madagascar Groupe Local des Partenaires de l'Education.

McCracken, Colleen. (2014, 15 September). What's Next for the Global Partnership for Education, Devex. Retrieved from https://http://www.devex.com/news/what-s-next-forthe-global-partnership-for-education-84324

Novelli, Mario. (2011). Are We All Soldiers Now? The Dangers of the Securitization of Education and Conflict. In K. Mundy \& S. Dryden-Peterson (Eds.), Educating Children in Conflict Zones: Research, Policy, and Practice for Systemic Change (A Tribute to Jackie Kirk) (pp. 49-65). New York: Teachers College Press.

OECD. (2007). Glossary of Statistical Terms: Fragile States. Retrieved 6 April, 2011, from http://stats.oecd.org/glossary/detail.asp?ID=7235 
Rome Declaration on Harmonisation (2003).

Rose, Pauline, \& Steer, Liesbet. (2013). Financing for Global Education: Opportunities for Multilateral Action. Washington, DC: Brookings.

Ross, Aaron, \& Rijasolo. (2013). Madagascar: When the Aid Dries Up, Untold Stories. Retrieved from http://pulitzercenter.org/projects/africa-madagascar-when-the-aid-dries-up

Save the Children. (2007). Last in Line, Last in School: How donors are failing children in conflict-affected fragile states. London: Save the Children Alliance.

Save the Children. (2009). Last in Line, Last in School 2009: Donor trends in meeting education needs in countries affected by conflict and emergencies. London: International Save the Children Alliance.

Save the Children. (2010). The Future is Now: Education for Children in Countries Affected by Conflict. London: Save the Children.

Savedoff, William. (2012). Global Government, Mixed Coalitions, and the Future of International Cooperation. Washington, DC: Center for Global Development.

Schemo, Diana. (2014, 24 June). Left Back: Results Lacking as Global Partnership Seeks Support for Education, 100 Reporters. Retrieved from http://100r.org/2014/06/left-backresults-lacking-as-global-partnership-seeks-support-for-education/

Schmidt, C., \& Taylor, A. (2010). Liberia's Education Pool Fund: A Case for Private Foundation Engagement in Post Conflict Education Recovery. from http://www.opensocietyfoundations.org/sites/default/files/liberia-education-pooled-fund20100831.pdf.

Sperling, G. (2007). How to unlock financing for Fragile States and Move towards a more unified global architecture of Education Financing. from http://www.cfr.org/content/thinktank/cue/bonn_5-21-2007.pdf.

Srtruye de Swielande, Dominique (2012, 20 June 2012). [Endossement du Plan Intérimaire de l'Education 2012-2014].

Transparency International. (2013). Corruption Perceptions Index 2013. Berlin: Transparency International.

Turrent, Victoria, \& Oketch, Moses. (2009). Financing universal primary education: An analysis of official development assistance in fragile states. International Journal of Educational Development, 29, 357-365. 
Turrent, Victoria, \& Oktech, Moses. (2009). Financing universal primary education: An analysis of official development assistance in fragile states. International Journal of Educational Development, 29, 357-365.

UNESCO. (2000). The Dakar Framework for Action: Education for All: Meeting our Collective Committments. Paris: UNESCO.

UNESCO. (2009). Education for All Global Monitoring Report: Overcoming Inequality. Oxford: Oxford University Press.

UNESCO. (2010). Education for All Global Monitoring Report 2010: Reaching the Marginalized. . Oxford: Oxford University Press.

UNESCO. (2011). Education for All Global Monitoring Report 2011: The hidden crisis: Armed conflict and education. Paris: UNESCO.

UNESCO. (2014). EFA Global Monitoring Report 2013-14, Teaching and Learning: Achieving Quality for All. Paris: UNESCO.

UNESCO Institute of Statistics. (2013). Leveraging statistical evidence to accelerate progress towards the education MDGs: Democratic Republic of the Congo country profile for Learning for All ministerial meeting, 18-19 April 2013. Montreal: UIS.

UNESCO. (2010). Education for All Global Monitoring Report 2010: Reaching the Marginalized. . Oxford: Oxford University Press.

UNHCR. (2014a). Facts and Figures about Refugees. Retrieved 6 January, 2015, from http://www.unhcr.org.uk/about-us/key-facts-and-figures.html

UNHCR. (2014b). UNHCR Global Trends 2013: War's Human Cost. Geneva: UNHCR.

UNICEF. (2014). Press release: With 15 million children caught up in major conflicts, UNICEF declares 2014 a devastating year for children. Retrieved 8 December, 2014, from http://www.unicef.org/media/media_78058.html

UNICEF Madagascar. (2012). Fast Track Initiative (FTI) /Global Partnership for Education (GPE) World Bank Donor Progress Report. Antananarivo: UNICEF.

United Nations. (2010). The right to education in emergency situations. New York: United Nations General Assembly.

United Nations. (2013). A New Global Partnership: Eradicate Poverty and Transforma Economies through Sustainable Development, The Report of the High-Level Panel of Eminent Persons on the Post-2015 Development Agenda. New York: United Nations. 
United Nations. (2014). 2014 Syria Regional Response Plan: Strategic Overview. New York: United Nations.

Watkins, Kevin, \& Zyck, Steven A. (2014). Living on hope, hoping for education: The failed response to the Syrian refugee crisis. London: Overseas Development Institute (ODI).

Winthrop, Rebecca, \& Matsui, Elena. (2013). A New Agenda for Education in Fragile States Center for Universal Education Working Paper. Washington, DC: Brookings.

World Bank. (2005). Le système éducatif de la république démocratique du Congo : Priorités et alternatives Human Development Series Working Paper. Washington, DC: World Bank, Africa Region.

World Bank. (2012). International Development Association Project Appraisal Document on a Proposed Grant in the Amount of US\$100 Million t the Democratic Republic of Congo for a Support to Basic Education Program Under the Global Partnership for Education Fund. Kinshasa: World Bank.

World Bank. (2013). Country Data Report for Congo, Dem. Rep., 1996-2012. Washington, DC: World Bank. 